\title{
NATURAL ENEMIES OF MICRASPIS CROCEA MULSANT (COLEOPTERA: COCCINELLIDAE)
}

\author{
MARILYN T. SABIJON \\ East-West Seed Co., Inc., San Rafael, Bulacan, Philippines
}

and

MARIA JULIET C. CENIZA

Department of Pest Management, Leyte State University

Visca, Baybay, Leyte, Philippines

\section{ABSTRACT}

Field survey and laboratory studies were conducted to gather information on the natural enemies of Micraspis crocea. A number of predators, parasitoids and entomopathogens were observed to be associated with this species of beetle. Among the predators, the spiders were quite common in the field attacking both the larvae and adult beetles. Four species of spiders, Tetragnatha maxillosa Thorell, Argiope catenulata Doelschall, Oxyopes lineatipes C.L. Koch and Lycosa pseudoannulata Bosenberg and Strand were recorded belonging to 4 families: Tetragnathidae, Araneidae, Oxyopidae and Lycosidae, respectively. Among the species, Oxyopes lineatipes had a high rate of consumption of the beetle larvae in the laboratory. Other insect predators observed included longhorned grasshoppers (Conocephalus longipennis), crickets (Metioche vittacolis Stal), carabid beetles (Ophionea nigrofasciata Schmidt-Goebel), and species of ant (Solenopsis germinata Fabricius). An Encyrtid wasp was also observed to parasitize the larvae of $M$. crocea while the white muscardine fungus, Beauveria bassiana Balsamo (Vuillemin) was found to infect the adult beetles in the field.

KEYWORDS: Coleoptera. Coccinellids. Micraspis crocea. Population dynamics. Host range. 


\section{INTRODUCTION}

Coccinellids or the ladybird beetles are very common and familiar group of beetles. They are of considerable economic importance because most species are predatory and known as an active biological control agent against agricultural insect pests. However, a comparatively small number of coccinellid species are potential plant pests, and one of this is the Micraspis crocea Mulsant (Pathak and Khan, 1994). They reportedly have mixed feeding habits. Adults and nymphs prefer to prey upon various aphid, leafhopper and planthopper nymphs and adults, stem borer eggs, and other soft-bodied, small insects such as thrips and mealybugs. In the absence of prey, however, they gnaw a hole through the rice hull to feed on the soft grain during the dough stage (Pathak and Khan, 1994). However, Burdeos (2002) concluded that $M$. crocea is a beneficial agent rather than a pest of rice since this beetle feed on insects attacking rice. Although the beetles take in rice pollen in the absence of the needed preys, it is very minimal and pollen produced during the flowering stage exceeds than what are needed for further development of the crop to produce considerable yield. Thus, loss of excess pollen due to consumption of the beetles may not be injurious to rice plants.

Very little is known about the predators, parasites and diseases of ladybirds, but there are some records of organisms attacking them, such as vertebrates, arthropods and microorganisms. Many species of spiders find ladybirds quite acceptable and are not deterred by the "reflex bleeding" of a ladybird that has blundered into a web (Majerus and Kearns, 1989). It is often observed that spiders feed on larvae and pupae of coccinellids. Older instars of Chrysopa spp. and Syrphus spp. feed also on the eggs and young instars of coccinellids (Kuznetsov, 1993 as cited by Hodek and Honek, 1996). Flies (Diptera), parasitic wasps (Hymenoptera), mites (Acarina) and roundworms (Nematoda) are also known to parasitize ladybirds. One of the most important ladybird beetle parasitoid is Perilitus coccinellae (Braconidae, Euphorinae), a small chalcid wasp of the genera Homalotylus and Tetrastichus. Moreover, microorganisms such as protozioa or the gregarines, Gregarina katherina, destroy intestinal cells ofcoccinellid larvae and adults and derive nourishment from their digestive tracts (Hodek and Honek, 1996). Some species of fungi such as Beauveria bassiana and Metarrhizium 
anisopliae are also considered as main biotic factor causing winter mortality of coccinellids. Some birds like swallows and swifts, which catch flying insects on the wing, do eat ladybirds (Majerus and Kearns, 1989).

In the Philippines, some studies have been conducted on the biology of some coccinellid beetles (Villacarlos and Robin, 1990; Mora, Gapud and Velasco, 1995; Garcia and Calilung, 1996; Balbarino, 1997; Pabroquez, 1998) but few published studies dealt on the natural enemies of these beetles. This study was done to gather information with the natural enemies of $M$. crocea in the field, particularly at the vicinity of the Leyte State University and the neighboring barangays.

\section{METHODOLOGY}

\section{Sampling Sites}

This study was conducted in the municipality of Baybay, in the western part of Leyte, Philippines. Leyte Island is one of the Visayas island groups located approximately between $124^{\circ} 17^{\prime}$ east longitude and between $9^{\circ} 55^{\prime}$ and $11048^{\prime}$ north latitude. The sampling sites were agricultural fields located in the vicinity of Leyte State University (LSU) campus and at Barangay Pangasugan, about $2.3 \mathrm{~km}$. north from LSU.

Collection of $M$. crocea beetles was done on rice (Oryza sativa L.), corn (Zea mays L.), sweetpotato (Ipomoea batatas Lam.), peanut (Arachis hypogaea L.), beans (Vigna sinensis L.), eggplant (Solanum melongena L.), squash (Cucurbita maxima Dcne.) and ampalaya (Momordica charantia L.), particularly during the flowering stage. 


\section{Survey and Collection of Micraspis crocea}

Fields of agricultural crops within LSU and neighboring barangays were surveyed particularly during the flowering stage of the crops. Plants where Micraspis crocea abound were identified and noted. Surrounding vegetation or plants growing in association with the crop were also identified. Likewise, potential predators and preys of $M$. crocea were observed and noted.

Ten net ( $32 \mathrm{~cm}$. dia) sweep samples covering 3-4 rows of plants in the selected sites were done to collect the adult beetles as well as the associated predators and parasitoids, while handpicking was done to collect the immature beetles. During the survey, observation on potential predators of the different developmental stages of this beetle was also made. However, this was mainly qualitative data since the number of individuals per species of predators was not recorded.

\section{Identification of Natural Enemies and Consumption Studies}

Observed predators and parasitoids in the field were collected and brought to the laboratory for identification and for further prey consumption studies using M. crocea. Field collected eggs, larvae and pupae of this beetle were placed individually in a petri plate lined with tissue paper. This was done to allow parasitoids to emerge from the beetles. Parasitoids that emerged from these individuals and predators were recorded and identified to the lowest level possible using available references. The parasitized beetles were dissected to determine the number of parasitoids that did not emerge.

For the prey consumption studies of potential predators, known number of different developmental stages of $M$. crocea were placed in a petri plate lined with tissue paper. Potential predators were starved for 24 hours and were individually introduced into each plate with the test insects for prey consumption studies. Each set-up was replicated five times. 


\section{RESULTS AND DISCUSSION}

\section{Natural Enemies}

A number of natural enemies were found associated with $M$. crocea in the field. These can be categorized into predators, parasitoids and entomopathogens.

Predators. A number of predators were identified and observed to prey on Micraspis crocea in the field (Fig. 1). Prey consumption studies in the laboratory also confirmed their feeding activity (Table 1): Most commonly encountered predators were the spiders, of which four species representing four families were identified. Other insect predators encountered were species of dragonflies (Agriocnemis sp. and Libellula sp.), long-horned grasshopper (Conocephalus longipennis), cricket (Metioche vittacolis), carabid beetle (Ophionea nigrofasciata) and an ant species (Solenopsis geminata).

Of the spiders, only A. catenulata fed on adult while others fed on larva with 0 . lineatipes having the highest number of larvae consumed (4 individuals/day). A. catenulata produced silk coating for the adult beetle prior to feeding making it helpless and immobile while others fed directly on the larvae by sucking its juice and leaving the exoskeleton behind. On the other hand, long-horned grasshopper, $C$. Iongipennis fed only on larvae while cricket, $M$. vittacolis fed on both eggs and larvae. Ophionea nigrofasciata fed only on eggs and rejected other stages of $M$. crocea. Among the predators observed, a species of ant, S. geminata, attacked all stages of the beetle, but the eggs were more preferred. The preyed larvae and pupae possessed dorso-abdominal holes that marked feeding punctures of the ant while the adult was held immobile by attacking first the legs then on the ventral side of the abdomen. Observation of Hodek and Honek (1996) on Lasius niger worker ants showed no hostility to coccinellid adults together with attended aphids. The protection given by ants to Homopteran (aphid) is related to their value as a food source. Among the arthropods studied, the Odonatans did not feed at all on M. crocea. 
The response could either be attributed to the non-preference of prey or the rearing container. Odonatans are highly mobile insects, even considered strong fliers and strong hunters and not a sit and wait predators. The enclosed container might have threatened the dragonflies, and influenced their feeding activity resulting to a negative response.

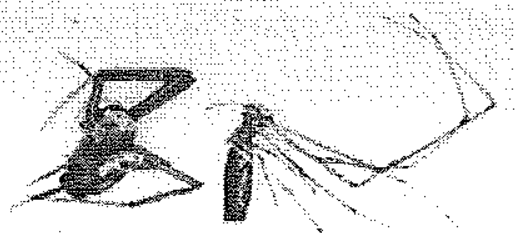

A $\quad B$
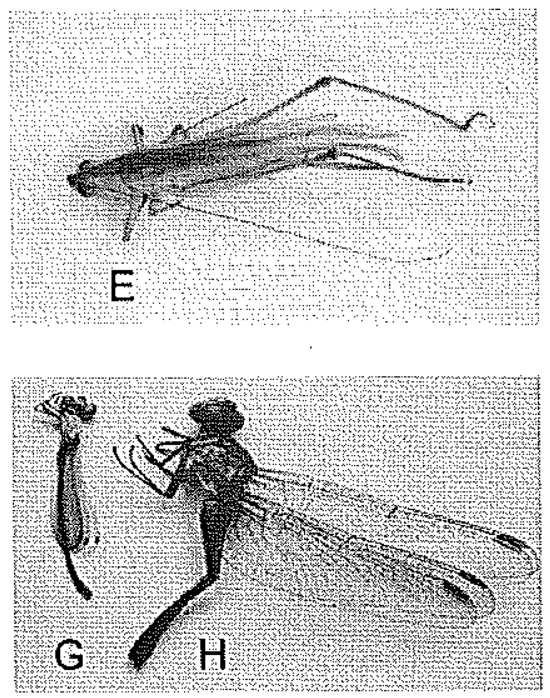
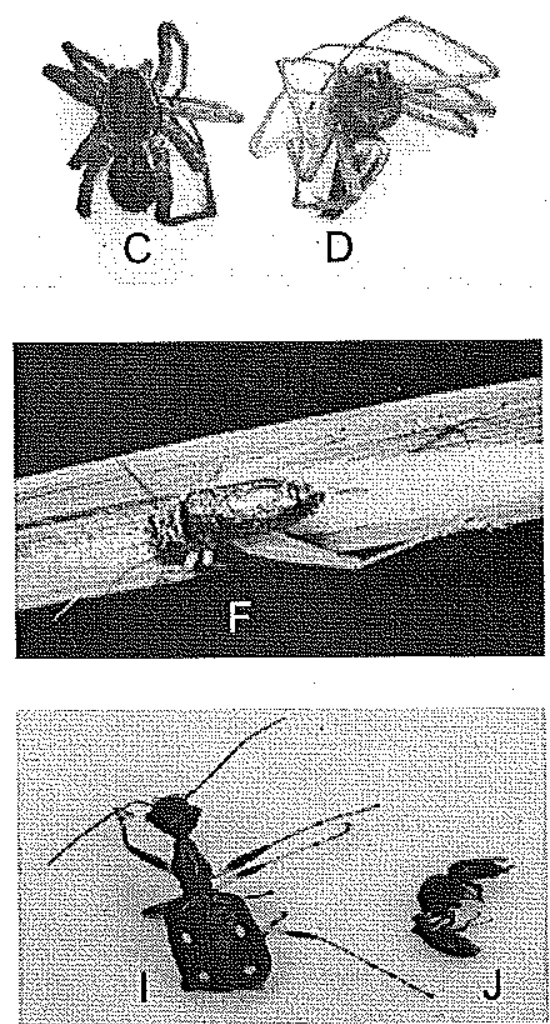

Figure 1. Arthropods that were observed to prey on $M$. crocea in the field; A) Argiope catenulata Doleschall, (1x); B) Tetragnatha maxillosa Thorell, (1x); C) Oxyopes lineatipes C.L. Koch, (1.5x): D) Lycosa pseudoannulata Boesenberg and Strand, $(1.5 x)$ E) Conocephalus longipennis de Haan, (1x) F) Metioche vittaticolis Stal, (1.5x); G) Agriocnemius sp. Rambur, (1x); H) Orthetrum sp. Gapud, (1x); I) Ophionea nigrofasciata Schmidt-Goebel, (2x); J) Solenopsis geminata Fab. (1x). 
Table 1. Consumption rate (daily) of the different predators on the different stages of Micraspis crocea

\begin{tabular}{|c|c|c|c|c|c|c|}
\hline Arthropods & Scientific Name & $\begin{array}{l}\text { Common } \\
\text { Name }\end{array}$ & $\begin{array}{l}\text { Total } \\
\text { Con } \\
\text { Eggs }\end{array}$ & arv & $\begin{array}{l}\text { cro } \\
\text { Dail } \\
\text { Pupa }\end{array}$ & $\begin{array}{l}\text { cea } \\
y^{*} \\
\text { Adult }\end{array}$ \\
\hline \multicolumn{7}{|l|}{ Aranae } \\
\hline Tetragnathidae & $\begin{array}{l}\text { Tetragnatha maxillosa } \\
\text { Thorell }\end{array}$ & $\begin{array}{l}\text { Long-jawed } \\
\text { spider }\end{array}$ & 0 & 3 & 0 & 0 \\
\hline Araneidae & $\begin{array}{l}\text { Argiope catenulata } \\
\text { Doleschall }\end{array}$ & Orb spider & 0 & 0 & 0 & 1 \\
\hline Oxyopidae & $\begin{array}{l}\text { Oxyopes lineatipes C.L. } \\
\text { Koch }\end{array}$ & Lynx spider & 0 & 4 & 0 & 0 \\
\hline Lycosidae & $\begin{array}{l}\text { Lycosa pseudoannulata } \\
\text { Boesenberg and Strand }\end{array}$ & Wolf spider & 0 & 2 & 0 & 0 \\
\hline \multicolumn{7}{|l|}{ Odonata } \\
\hline Coenagrionidae & Agriocnemius s.p. & Damselfly & 0 & 0 & 0 & 0 \\
\hline Libellulidae & Libellula s.p. & Dragonfly & 0 & 0 & 0 & 0 \\
\hline \multicolumn{7}{|l|}{ Orthoptera } \\
\hline $\begin{array}{l}\text { Tettigoniidae } \\
\text { Gryllidae }\end{array}$ & $\begin{array}{l}\text { Conocephalus longipennis } \\
\text { de Haan }\end{array}$ & $\begin{array}{l}\text { Long-horned } \\
\text { grasshoper }\end{array}$ & 0 & 1 & 0 & 0 \\
\hline $\begin{array}{c}\text { Gryllidae } \\
\text { Coleoptera }\end{array}$ & Metioche vittaticolis Stal & Cricket & 3 & 1 & 0 & 0 \\
\hline \multicolumn{7}{|l|}{ Coleoptera } \\
\hline Carabidae & $\begin{array}{c}\text { Ophionea nigrofasciata } \\
\text { Schmidt-Goebel }\end{array}$ & Ground beetle & 10 & 0 & 0 & 0 \\
\hline \multicolumn{7}{|l|}{ Hymenoptera } \\
\hline Formicidae & $\begin{array}{l}\text { Solenopsis geminata } \\
\text { fabricius }\end{array}$ & Red ant & 32 & 2 & 1 & 1 \\
\hline
\end{tabular}

${ }^{*}$ consumption based on five replications.

Parasitoids. M. crocea was found to be parasitised by small chalcid wasp of the family Encyrtidae, subfamily Eupelminae. Third and fourth instar parasitised larvae were found attached to the upper surface of rice leaves as though preparing to molt but instead they swelled and the cuticle hardened and darkened. The body of the parasitised larva was deformed and appeared to be twisted with visible waist-like abdominal and 
thoracic divisions (Fig. 2). The distorted larvae were dry, legs spread apart and tarsal claws were observed to be missing. The parasitic wasp consumed all fundamental organs and body tissues of the host were used-up as food source of the developing wasp inside resulting to a dry-up cuticle. Commonly, the anterior part of the body seemed raised from the leaf substrate leaving the posterior part attached to the leaf. Since these beetles were field collected, development of the parasitoid was not monitored. However, based on observation, emergence of parasitoid varied from 2-4 days after collection while some parasitoids did not emerge at all (Table 2). It was observed that a single larva contained 3-5 Encyrtids or an average of 4 parasitoids were found per larva. However, only a maximum of 2 wasps emerged although most commonly only one wasp emerged or around $25 \%$ emergence only. Low average percent emergence of parasitoids (21\% first cropping and $20 \%$ second cropping) maybe attributed to death of parasitoids due to multiparasitism. However, this phenomenon may not be conclusively proven at this point in time, since no thorough study was made on the cause of the non-emergence of the other parasitoids in the beetle larvae.

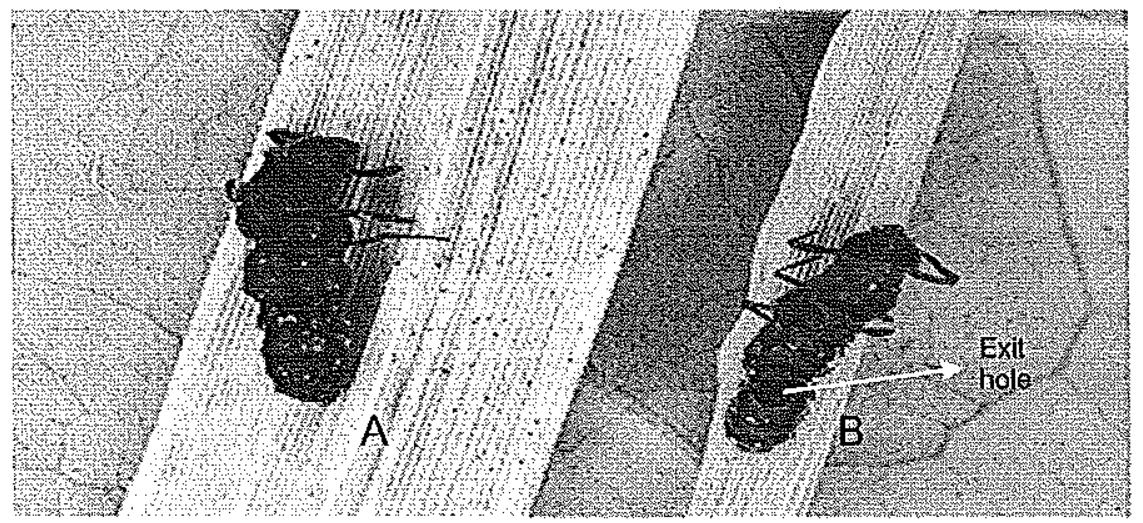

Figure 2. Parasitized larvae of $M$. crocea. A) twisted body with visible constrictions along its length; $B$ ) with visible exithole ( $8 \mathrm{x})$. 
The adult wasp escaped from the dorso-abdominal wall of the beetle by boring a small hole in the cuticle. The adult wasp (Fig. 3 ) is metallic blue. The elbowed antennae have 10 segments; the terminal segment whitish or cream in color and the ninth segment is the longest. The tarsi of the middle legs are whitish or cream in color and possessed spurs. Wings are clear with black light spots and abdomen has small but visible ovipositor.

Table 2. Field parasitism of and parasitoid emergence from $M$. crocea larvae.

\begin{tabular}{c|c|c|c|c|c|c}
\hline \hline $\begin{array}{c}\text { Cropping } \\
\text { season }\end{array}$ & $\begin{array}{c}\text { Total \# } \\
\text { larvae } \\
\text { collected }\end{array}$ & $\begin{array}{c}\text { Parasitized } \\
\text { larvae \# }\end{array}$ & $\begin{array}{c}\text { Percent } \\
\text { Parasitism } \\
(\%)\end{array}$ & \multicolumn{2}{|c|}{$\begin{array}{c}\text { Number of } \\
\text { parasitoids } \\
\text { Inside } \\
\text { the host }\end{array}$} & \multicolumn{2}{c}{$\begin{array}{c}\text { Average } \\
\text { Emergence } \\
(\%)\end{array}$} \\
\hline $1^{\text {st }}$ & 68 & 11 & 16 & $3-5$ & $0-2$ & 21 \\
\hline $2^{\text {m }}$ & 75 & 5 & 7 & 4 & $0-2$ & 20 \\
\hline \hline
\end{tabular}

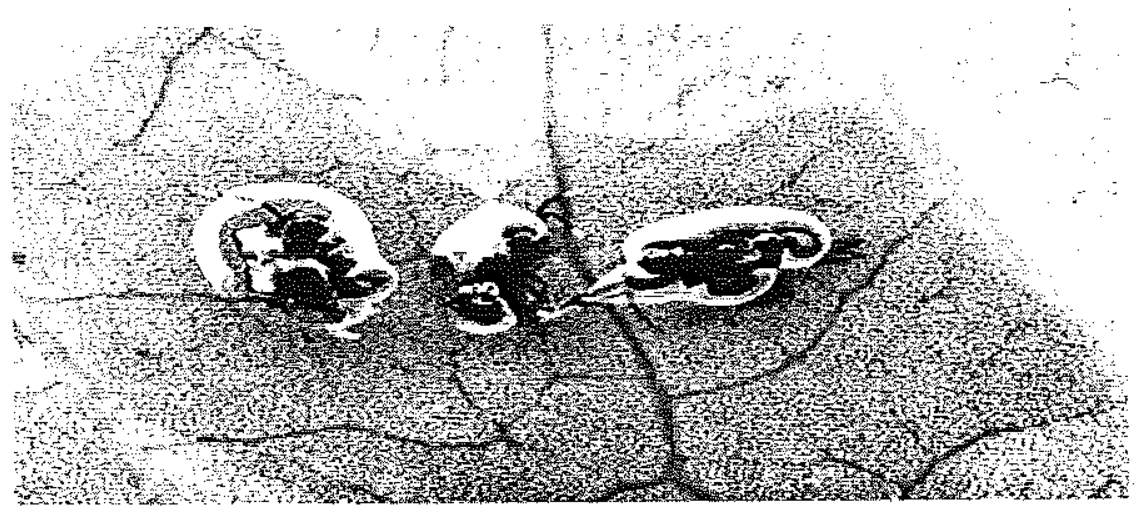

Figure 3. Adult Encytid parasitoids (Hymenoptera: Chalcidoidea: Encyrtidae) (20x). 
Entomopathogen. Microorganisms causing diseases are considered as natural mortality factor not only among insect pests but also among beneficial insects. Majerus and Kearns (1989) mentioned that many species of fungal pathogens, Hyphomycetes (Deuteromycotina), are common pathogens of a range of insects, but particularly one, Beaveria bassiana (Balsamo) Vuillemin is reported to affect coccinellids. $B$. bassiana of the order Moniliales was the only fungal pathogen observed in the study to infect M. crocea. The fungus is commonly called as "white muscardine" because of the white mycelial mat surrounding the infected insect (Fig. 4). The fungus invades the soft tissues and body fluids of its host and grows out of the body when ready to produce spores. The spore germinates and penetrates the host integument using a complex of cuticle-degrading enzymes (Hodek and Honek, 1996). When the germ tube enters the insect body, it may produce blastospores, which circulate in the haemolymph and occupy various organs and tissues. Subsequent hyphal growth leads to mechanical damage which, combined with nutrient exhaustion and release of toxins, causes death of the host. Proliferating hyphae overgrow the cadaver and produce spores.

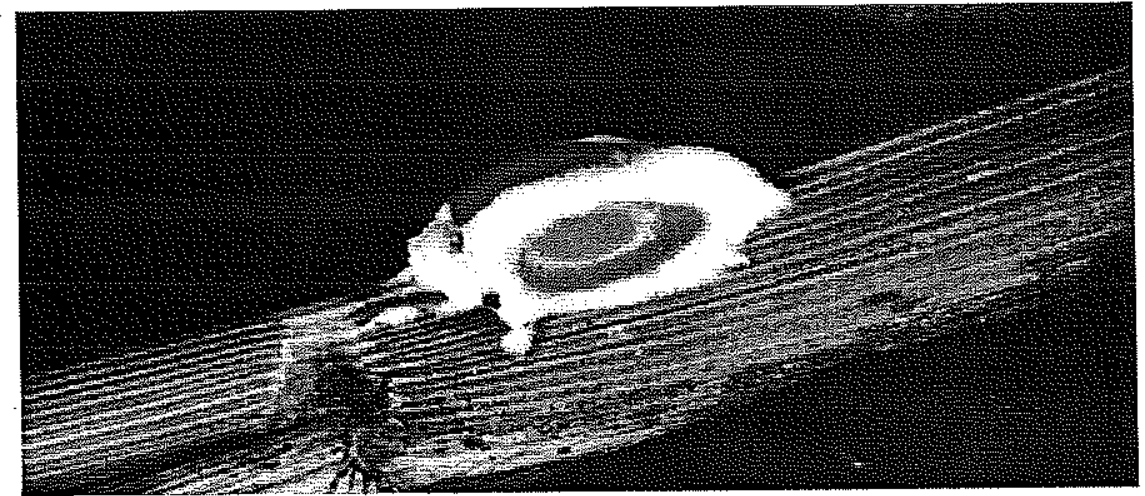

Figure 4. Adult of M. crocea infected by Beauveria bassiana (Balsamo) Vuillemin (20x). 


\section{CONCLUSION AND RECOMMENDATION}

One of the biotic factors controlling the presence and population of $M$. crocea in the field were the natural enemies. These included some species of arthropod predators, among which were mainly the spiders and other species of insect predators. Only one hymenopterous parasitoid, an Encyrtid wasp, was observed while a fungal entomopathogen, $B$. bassiana, was found to infect $M$. crocea in the field. These organisms influenced the abundance of these beetle species.

Although prey consumption studies have been done for potential predators, in-depth quantitative studies may be relevant to validate mortality effect of these natural enemies on this species of beetle.

\section{LITERATURE CITED}

BALBARINO, B.C. 1997. Biology and Feeding Behavior of Coccinella transversalis Mulsant (Coccinellidae : Coleoptera). BSA Thesis. Visayas State College of Agriculture, Baybay, Leyte. 40p.

BURDEOS, M.M. 2002. The Role of Micraspis crocea Mulsant (Coleoptera: Coccinellidae) in the Rice Ecosystem. BSA Thesis. Leyte State University. Visca, Baybay, Leyte. 43p.

GARCIA, A.U. and V.J. CALILUNG. 1996. The biology of Scymnus trukensis Chapin (Coleoptera: Coccinellidae) on Pentalonia nigronervosa Coquerel (Hemiptera: Aphididae). Phil. Entom. (2):139-161.

HODEK, I. and A. HONEK. 1996. Ecology of Coccinellidae. Kluwer Academic Publ., Netherlands. 463p. 
MAJERUS, M. and P. KEARNS. 1989. Ladybirds. The Richmond Publishing Co., Ltd., Great Britain. 103p.

MORA, J.G., V.P. GAPUD and L.R.I. VELASCO. 1995. The life history and voracity of Coelophora inaequalis (Fabricius) (Coleoptera: Coccinellidae) on Aphis craccivora Koch (Hemiptera: Aphididae). Phil. Entom. 9(5):523-553.

PABROQUEZ, L.P. 1998. Biology and Feeding Behavior of Synonycha grandis Thunberg (Coleoptera: Coccinellidae). BSA Thesis. Visayas State College of Agriculture, Baybay, Leyte. 42p.

PATHAK, M.D. and Z.R. KHAN. 1994. Insect Pests of Rice. IRRI, Manila, Phil. pp.61-62.

POWERS, L.E. and R. MCSORLEY. 2000. Ecological Principles of Agriculture. Delmar Thomson Learning, USA.433P.

PRRI. 1991. Field Guide: On Harmful and Useful Organisms in Philippine Ricefields (Insects and Non-insects). Maligaya, Muñoz, Nueva, Ecija. 34p.

VILLACARLOS, L.T. and N.M. ROBIN. 1992. Biology and potential of Curinus coeruleus Mulsant. an introduced predator of Heteropsylla cubana Crawford. Phil. Entom. (6): 1247-1258. 


\section{ABOUT THE AUTHOR}

The author obtained her Bachelor of Science

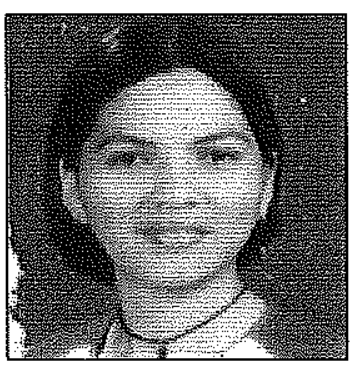
in Agriculture in 1997 from the Visayas State College of Agriculture, now the Leyte State University, and her Master of Science in Plant Protection in 2004.

Currently, she is employed at the East-West Seed Co., Inc in San Rafael, Bulacan as Junior Technology Transfer Specialist.

The co-author is a professor of the Department of Pest Management, Leyte State University, and is the major adviser of the senior author. 